\title{
Identifying some Additional Rust Resistance Genes in Indian Wheat Varieties Using Robust Markers
}

\author{
H. Khan, S.C. Bhardwaj*, O.P. Gangwar, P. Prasad, P.L. Kashyap, S. Savadi, \\ S. KUMAR and R. RATHORE \\ ICAR - Indian Institute of Wheat and Barley Research, Regional Station, Flowerdale, Shimla-171002, India \\ (Received 20 December 2016; Accepted 28 March 2017; \\ Communicated by J. Kolmer)
}

\begin{abstract}
A set of forty wheat cultivars comprising bread wheat, durum and triticale identified during 2010-2014 were tested for resistance to Indian pathotypes of leaf, stem and yellow rusts at seedling stage under controlled conditions. Eight $\mathrm{Lr}$ genes ( $\mathrm{Lrl}, \mathrm{Lr} 3, \mathrm{Lr} 10, \mathrm{Lr} 13, \mathrm{Lr} 14 \mathrm{a}$, $L r 23, L r 24$ and $L r 26$ ) were characterized based on differential interactions with specific rust races. Genes $L r 23, L r 26$ and $L r 13$ conferred leaf rust resistance in most of the accessions. Three $Y r$ genes $(Y r A, Y r 2$ and $Y r 9)$ were inferred in 40 genotypes, where $Y r 2$ followed by $\operatorname{Yr} 9$ were most frequent in conferring stripe rust resistance. Ten $S r$ genes, namely, $S r 2, S r 5$, $\operatorname{Sr} 8 a, \operatorname{Sr} 7 b, \operatorname{Sr} 9 b, \operatorname{Sr} 9 e, \operatorname{Sr} 11, \operatorname{Sr} 13$, $S r 24$ and $\operatorname{Sr} 31$, were postulated in these lines with predominance of $\mathrm{Sr} 11, \mathrm{Sr} 31$ and $\mathrm{Sr} 2$. These $\mathrm{Lr}, \mathrm{Sr}$ and $\mathrm{Yr}$ genes were observed singly or in combination. Robust DNA markers were used to identify adult plant resistance genes $\mathrm{Yr} 18 /$ Lr34/Sr57, Lr68 and Sr2 and all stage resistance genes $\operatorname{Lr} 24 / \mathrm{Sr} 24, \mathrm{Sr} 28$ and $\mathrm{Yr}$ 9/Lr26/Sr31. STS marker iag95 showed presence of $Y r 9$ in four additional cultivars which were resistant to one or more rusts. Gene $\operatorname{Sr} 28$ was identified in seven durum cultivars with the wPt7004 marker. This is first report of $S r 28$ being present in many Indian wheat cultivars. CsGs-STS marker identified $\operatorname{Lr68}$ in nine cultivars.
\end{abstract}

Keywords: wheat, Puccinia, rust resistance, gene postulation, molecular marker

\section{Introduction}

Three rusts (stripe, leaf and stem rust) are economically the most important diseases of wheat as they pose major threat to wheat production in most of the wheat growing areas of the world. Rust pathogens are continuously evolving and acquiring virulence to more resistance genes (Stubbs 1985). The wheat rusts are caused by three species of the fungal genus Puccinia: stripe rust by Puccinia striiformis f. sp. tritici Eriks. (Pst); leaf rust by Puccinia triticina Eriks. (Pt); and stem rust by Puccinia graminis f. sp. tritici Eriks. \& E. Henn $(P g t)$. Generally, these pathogens are confined to wheat, however, some of these can occur to a small extent on barley and grasses.

Deployment of rust resistant cultivars has been the most economical and environmentally friendly strategy to control rust diseases. The concept of growing rust resistant cultivars dates back to the early twentieth century (Biffen 1931) and breeding for rust resist- 
ance has since been a major objective. To date, $59 \mathrm{Sr}$ genes, $77 \mathrm{Lr}$ and $78 \mathrm{Yr}$ genes in wheat have been mapped with defined chromosome location and given gene designations (McIntosh et al. 2017). Since rusts are obligate parasites, any resistance genes in host cultivars that restrict or eliminate rust reproduction will facilitate selection of variants that are virulent to resistance genes. Rust resistance based on major genes has not been generally durable as the pathogen can change to render such genes ineffective. In contrast, resistance based on slow rusting genes with additive effects was reported to be durable (Johnson 1988; Singh 1992; Bhardwaj 2013). The presence of a slow rusting type of adult plant resistance (APR), which expresses generally after third leaf stage, is well documented in wheat (Singh and Rajaram 1994; Bariana and McIntosh 1995; Bansal et al. 2014). APR genes of both race specific and non-race specific nature are available, and combinations of both may provide durable resistance (Saini et al. 2002; Bhardwaj et al. 2010a). Cultivars with combinations of race non-specific resistance genes have remained resistant over a period of years even though races of the rust population have changed frequently (Bariana and McIntosh 1995; Singh et al. 2000; Bariana et al. 2007).

Resistance gene postulation by multi-pathotype tests is a rapid means by which the resistance genes present in a host genotype can be characterized (Loegering et al. 1971). It is based on gene-for gene specificity between host resistance genes and different avirulence genes. A well-characterized collection of pathogen pathotypes with different avirulence gene combinations is used to postulate the resistance genes in host genotypes. However, interaction between resistance genes can obscure the gene postulation and this method is best suited for seedling resistance genes (Kolmer 1996). Problems in gene identification like gene interaction and plant growth stage at which genes are expressed can be overcome by using DNA based markers (McCartney et al. 2005). Moreover, genes most effective in adult plant stage that provide resistance against all pathotypes of the rust cannot be postulated by multi-pathotype tests. Therefore, the present study was carried out to identify the rust resistance genes in forty varieties using gene postulation technique and known genetic markers for important adult plant rust resistance genes.

\section{Material and Methods}

\section{Host material}

Forty varieties identified 2010-2014 were used in this study. The study material consisted of hexaploid wheat (bread), durum, and triticale. Pedigree details of these lines are mentioned in Table 3.

\section{Pathogen material}

Multi-pathotype testing of these forty wheat genotypes was done for three rusts of wheat. Twenty-six pathotypes of leaf rust, 25 of stem rust and 14 of stripe rust with different avirulence/virulence structure were used in the study (Table 1). These pathotypes are being maintained in the national repository at Regional Station ICAR - Indian Institute of Wheat and Barley Research, Flowerdale, Shimla. 
Table 1. Rust pathotypes used for testing Indian wheat cultivars

\begin{tabular}{|c|c|c|c|c|}
\hline \multicolumn{2}{|c|}{ Leaf rust } & \multicolumn{2}{|c|}{ Black rust } & \multirow{2}{*}{$\frac{\text { Stripe rust }}{\text { Binomial notation }}$} \\
\hline $\begin{array}{l}\text { Indian pathotype } \\
\text { Binomial notation* }\end{array}$ & $\begin{array}{c}\text { North American } \\
\text { equivalent }\end{array}$ & $\begin{array}{l}\text { Indian pathotype } \\
\text { Binomial notation* }\end{array}$ & $\begin{array}{c}\text { North American } \\
\text { equivalent }\end{array}$ & \\
\hline 0R8 (11) & $\mathrm{BBBBB}$ & 79G31 (11) & RRTSF & $66 \mathrm{~S} 64(14 \mathrm{~A})$ \\
\hline 5R5 (12) & FGTTL & $203 \mathrm{G} 15$ (11A) & RHTSF & $70 S 74(20 \mathrm{~A})$ \\
\hline 1R5 (12-2) & FGTTL & $123 \mathrm{G} 15(15-1)$ & TKTSF & 66S64-1 (38A) \\
\hline 29R45 (12-5) & FHTPM & 9G5 (21) & CHMSC & 67S64 (31) \\
\hline 93R37 (12-9) & FHTTM & 24G5 (21-1) & CKMSC & 7S4 (A) \\
\hline 5R9-7 (16-1) & DBBPB & $75 \mathrm{G} 5(21 \mathrm{~A}-2)$ & CHTSC & $38 \mathrm{~S} 102$ (I) \\
\hline 45R31 (77) & TGTPB & $5 \mathrm{G} 19(24 \mathrm{~A})$ & HRCSC & $47 \mathrm{~S} 102(\mathrm{~K})$ \\
\hline 109R63 (77-1) & ТНTTB & 10G13 (34-1) & MHGSF & $70 \mathrm{~S} 69$ (L) \\
\hline 109R31-1 (77-2) & TGTTL & $62 \mathrm{G} 29(40 \mathrm{~A})$ & PTHSC & $46 \mathrm{~S} 102(\mathrm{~N})$ \\
\hline 121R63-1 (77-5) & THTTM & $62 \mathrm{G} 29-1(40-1)$ & PTHSM & $46 \mathrm{~S} 103(\mathrm{P})$ \\
\hline 121 R127 (77-7) & TRTTL & $58 \mathrm{G} 13-3(40-2)$ & PKRSC & $47 \mathrm{~S} 103(\mathrm{~T})$ \\
\hline 253R31 (77-8) & TGTTL & $127 \mathrm{G} 29(40-3)$ & PTTSF & $46 \mathrm{~S} 119$ \\
\hline 121 R60-1 (77-9) & MHTKL & $7 \mathrm{G} 35$ (42B) & HRHSC & $78 \mathrm{~S} 84$ \\
\hline 377R60-1 (77-10) & MHTKQ & $36 \mathrm{G} 2$ (117A) & JRCSC & $110 \mathrm{~S} 119$ \\
\hline 121R52-1 (77-12) & MGTNL & 38G18 (117A-1) & JRHSC & \\
\hline 109R23 (77A-1) & TGTTL & 166G2 (117-1) & JRHSC & \\
\hline 21R55 (104-2) & PHTTL & 33G3 (117-2) & KHCSC & \\
\hline 21R63 (104-3) & PHTTL & 167G3 (117-3) & KRHSC & \\
\hline 93R57 (104-4) & NHKSP & 166G3 (117-4) & KRHSC & \\
\hline 29R23 (104B) & MGTDL & 166G2-2 (117-5) & JRHSC & \\
\hline 0R9 (106) & BBBBB & $37 \mathrm{G} 19(117-6)$ & KRCSC & \\
\hline 45R35 (107-1) & JCGKL & $7 \mathrm{G} 11$ (122) & RRHSC & \\
\hline 57R27 (108-1) & SGTPC & 53G1 (184) & FTCSC & \\
\hline 93R47 (162-1) & КНTTM & 54G1 (184-1) & FTHSC & \\
\hline 29R07 (162-3) & KGTPL & 7G43 (295) & RRHSC & \\
\hline 93R15 (162A) & KGTSB & & & \\
\hline
\end{tabular}

*Name in parenthesis represents vernacular Indian names whereas binomial designations are based on Nagarajan et al. (1986).

\section{Inoculation and disease assessment}

Eight seeds of each line were sown in $10 \mathrm{~cm}$ pots filled with a mixture of fine loam and farmyard manure (3:1) and four lines per pot were sown. After sowing, pots were maintained in rust-free microclimate rooms at $20{ }^{\circ} \mathrm{C}$. Inoculations were performed on oneweek-old seedlings stage using urediniospores suspended in a light weight, non-phyto- 


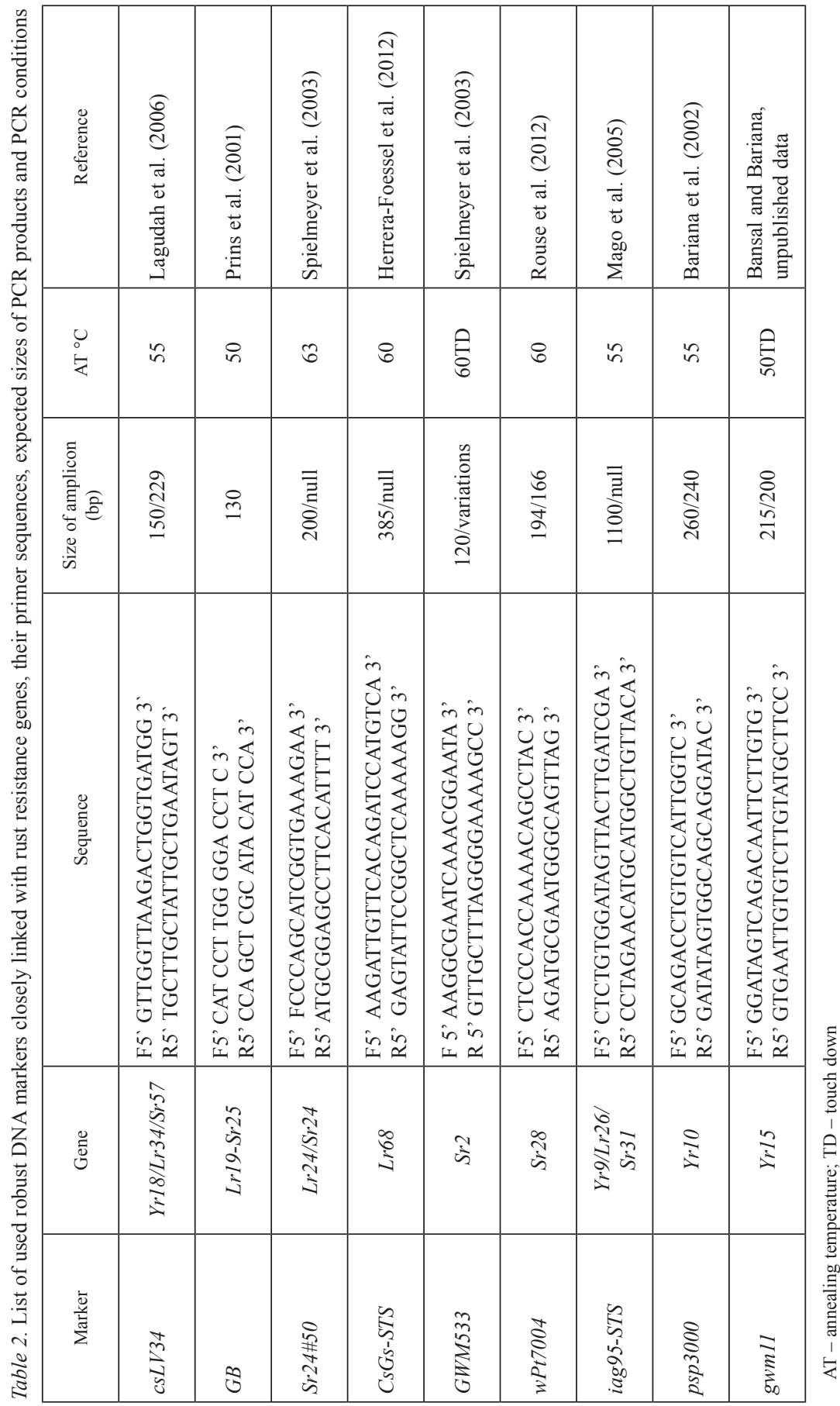


toxic isoparaffinic oil (Soltrol, $2 \mathrm{mg}$ spores per $5 \mathrm{ml}$ oil per 50 pots) using an atomiser. Inoculated seedlings were placed in dew chambers that allowed high humidity, and incubated in the dark at $10-12{ }^{\circ} \mathrm{C}$ for $24 \mathrm{~h} ; 20-22^{\circ} \mathrm{C}$ for $24 \mathrm{~h}$; and $22 \pm 2{ }^{\circ} \mathrm{C}$ for $24 \mathrm{~h}$ for stripe, leaf, and stem rusts, respectively. A full set of differentials (Bhardwaj et al. 2012) was also included in each inoculation for seedling resistance test to determine purity of pathotypes (Table S1*). Subsequent to incubation, seedlings were transferred to temperature and irrigation-controlled greenhouse rooms at $17^{\circ} \mathrm{C}, 22^{\circ} \mathrm{C}$ and $25^{\circ} \mathrm{C}$ for stripe, leaf, and stem rusts, respectively. Rust scoring was done after 14 days of inoculation. In this study, the gene postulation method was used to identify probable genes that condition seedling resistance in forty identified wheat varieties. Infection types (ITs) were based on the 0-4 scale based on Stakman et al. (1962), with slight modifications as proposed by Luig (1983), where IT0 represents the lowest incompatible resistant reaction and IT4 depicts fully compatible susceptible reaction. Infection type ITX, referred to as mesothetic, produces a mixture of incompatible and compatible infection types on the same leaf and is classed as resistant. Resistance genes were postulated by comparing IT patterns of the pathotype array on test material with those of controls with known resistance genes (Browder 1973; Nayar et al. 1997). High ITs on a test cultivar with pathotypes that are avirulent to a known resistance gene, indicated that the cultivar did not possess the gene in question.

\section{PCR amplification and product analysis}

Leaf tissue was harvested from 12-day-old seedlings of each genotype and DNA was extracted using the CTAB method following the procedure described in Bansal et al. (2010). The DNA samples were quantified using Biophotometer D30 (Eppendorf). Polymerase chain reaction (PCR) amplifications were performed in $10 \mu \mathrm{L}$ volumes with final concentrations containing $30 \mathrm{ng}$ genomic DNA, $0.2 \mathrm{mM}$ dNTPs, $0.5 \mu \mathrm{M}$ of each primer, 10x PCR buffer with $15 \mathrm{mM} \mathrm{MgCl}_{2}$ and $0.3 \mathrm{U}$ Taq DNA polymerase (Genaxy). A touchdown PCR profile was used to amplify SSR markers (Don et al. 1991). PCR was performed in a Veriti96 Thermal Cycler (Applied Biosystems) using a touchdown profile comprising initial denaturation at $95^{\circ} \mathrm{C}$ for $10 \mathrm{~min}$, followed by 35 cycles of denaturation at $94{ }^{\circ} \mathrm{C}$ for $60 \mathrm{~s}$, annealing at (varied with primer) for $30-60 \mathrm{~s}$ and extension at $72{ }^{\circ} \mathrm{C}$ for $60 \mathrm{~s}$. The microsatellite markers for known rust resistance genes (Table 2) were used for identification and validation of rust resistance genes in the selected wheat genotypes. PCR products were resolved on $2.5 \%$ agarose made using $1 \times$ TAE buffer and pre-stained with ethidium bromide. 29 bromophenol dye and pUC19 DNA/MspI 100 bp (HpaII) was used as a ladder to determine fragment sizes. The PCR products were separated using a Bio-Rad Sub-Cell 192. Gel imaging was done in Vilber Lourmet gel documentation system. SSR allele scoring was performed using Gene Mapper v 4.0 software (Applied Biosystems). Proper negative and positive control DNAs were included in each of the marker analysis and observations were repeated to ascertain the accuracy of the results.

*Further details about the Electronic Supplementary Material (ESM) can be found at the end of the article. 


\section{Results}

Seedling resistance analysis using multi-pathotype screening

Rust resistance genes ( $\mathrm{Lr}, \mathrm{Sr}$ and $\mathrm{Yr}$ ) were characterized in forty varieties using gene postulation technique based on rust infection types. Rust resistance genes present in host genotypes were postulated by comparing the infection type data generated from a set of pathotypes (Table 1, Table S2) with that of differential hosts with single resistance genes under same set of conditions. Table 3 shows the genes postulated in the forty genotypes for three rusts. Eight $L r$ genes ( $L r 1, L r 3, L r 10, L r 13, L r 14 a, L r 23, L r 24$ and Lr26 present singly or in combination) were identified in 40 lines where differential host pathogen interactions were observed. Genes $L r 23, L r 26$ and $\operatorname{Lr} 13$ were observed in many lines. Ten

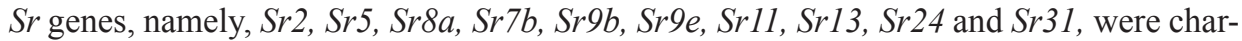
acterized in forty genotypes. Genotypes with $S r 24 / L r 24$ were inferred based on susceptibility to pathotype 40-1 of stem rust and resistance to remaining pathotypes as well as to leaf rust pathotypes in two cultivars. $\mathrm{Sr} 31$ thought resistant to stem rust in India, was postulated based on its tight linkage with $\mathrm{Yr} 9 / \mathrm{Lr} 26$. Sr2 was characterized based on micro-flecking of seedlings which is independent of rust infection. Among $\mathrm{Sr}$ genes postulated $\operatorname{Sr} 11, \operatorname{Sr} 31$ and $S r 2$ were the most frequently found. Three $\operatorname{Yr}$ genes ( $Y r 2, \operatorname{YrA}$ and $\left.Y_{r} 9\right)$ were characterized in 33 genotypes. Among these, $Y r 2$ was inferred in 22 lines followed by $\operatorname{Yr} 9$, which was characterized in seven lines.

\section{Gene identification through molecular markers}

To determine identity of the adult plant resistance and find additional rust resistance, robust molecular markers were applied to the 40 lines. Validated molecular markers (Table 2) were used for identification of three commonly found APR genes Lr34/Yr18/ $S r 57, \operatorname{Lr} 68$ and $S r 2$. In addition $L r 24 / S r 24, \operatorname{Yr} 9 / \operatorname{Lr} 26 / S r 31$ and $S r 28$ seedling rust resistance genes were also identified with molecular markers.

The presence of the $150 \mathrm{bp}$ amplicon from $c s L V 34$ marker showed that gene complex Lr34/Yr18/Sr57/Pm38 is present in eight genotypes DBW71, DBW107, HI1563, HPW349, HS507, HS542, PBW644 and RAJ4229. Presence of the 229 bp amplicon indicated the absence of $\operatorname{Lr} 34$. In addition, all of these eight lines possessed progressive leaf tip necrosis, too. Dominant marker Sr24\#50 which indicates the presence of $\mathrm{Lr} 24 / \mathrm{Sr} 24$ produced amplicon of 200 bp in seven varieties, namely, HD3090, HI1563, HW5216, MP3288, NIAW1415, RAJ4229 and RAJ4238. All the seven varieties validated for presence of $\mathrm{Lr} 24 / \mathrm{Sr} 24$ gene by the marker had complete resistance against all the pathotypes of leaf rust. These seven varieties were resistant to all stem rust pathotypes except 40-1. The dominant marker CsGS identified $\operatorname{Lr} 68$ adult plant resistance gene in nine cultivars: DBW90, DBW110, HD3043, HD3086, HD3118, HS542, K1006, PBW644 and WH1080. Based on presence of 120 bp band from gwm 533 marker Sr 2 was confirmed in five varieties, HI8713, HI8737, HW1098, PDW315 and UAS428. All these lines possessed mottling at seedling stage as well as pseudo-black chaff at adult plant stage. All other variations from $120 \mathrm{bp}$ amplicon indicate absence of Sr2. Marker wPt7004 confirmed presence 


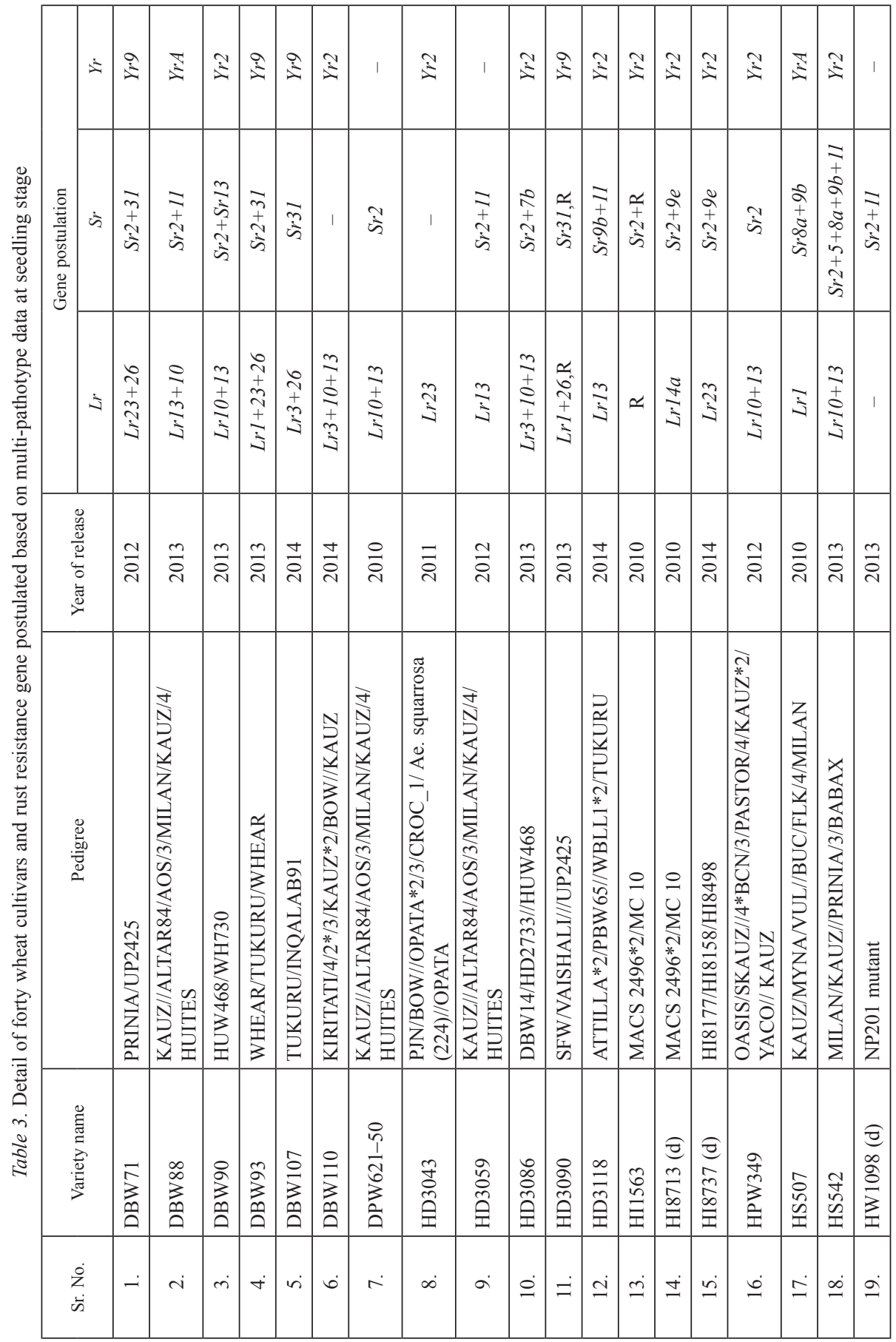




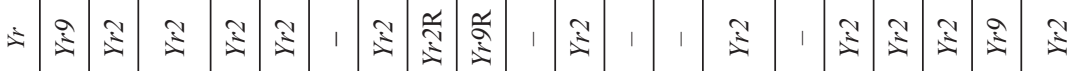

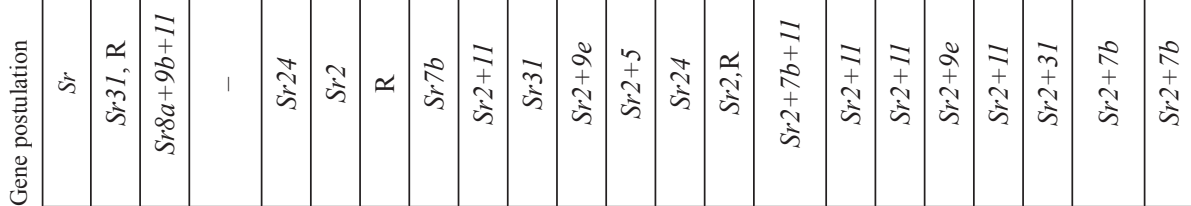

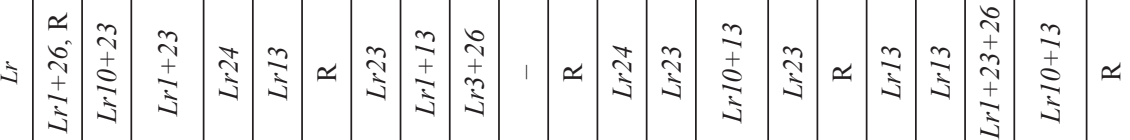

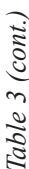

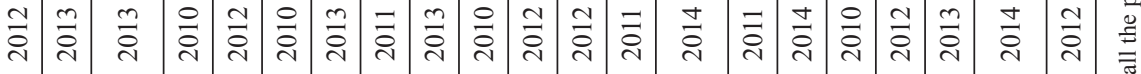

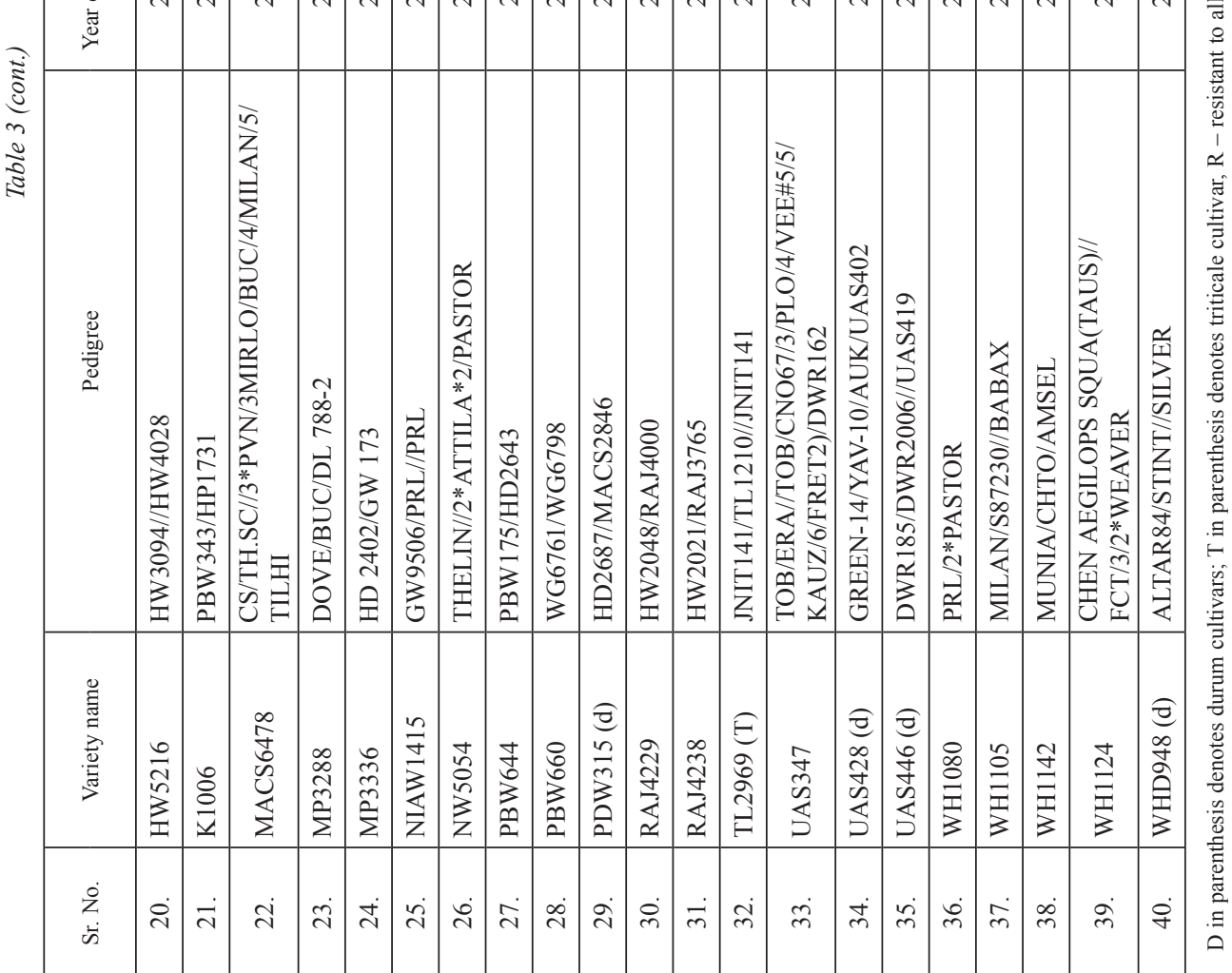


of $\mathrm{Sr} 28$ gene in seven durum varieties, HI8713, HI8737, HW1098, PDW315, UAS428, UAS446 and WHD948. The presence of the 194 bp amplicon identified Sr 28 gene and preferential amplicon of $166 \mathrm{bp}$ or equal amplification of both the band indicated absence of the gene.

Presence of $\mathrm{Yr} 9 / \mathrm{Lr} 26 / \mathrm{Sr} 31$ was validated by iag95-STS marker, which produced 1100 bp band in eleven varieties, namely, DBW71, DBW93, DBW107, HD3043, HD3090, HS507, HW5217, NIAW1415, PBW660, TL2969 and WH1142. Yr9 was postulated in seven varieties using multi-pathotype data but iag95-STS marker showed presence of the gene in four additional varieties, namely, DBW71, HD3043, HS507 and TL2969, and validated the presence of $\operatorname{Yr} 9$ in seven varieties.

Markers for $\operatorname{Yr} 9$ and $\operatorname{Yr} 15$ (Table 2) were also used to explore the presence of these genes in fully stripe rust resistant lines, however none of the cultivars were positive for the markers. Marker $G B$ for $L r 19 / S r 25$ was not amplified in any of the cultivar.

Table 4. Rust resistance gene identified through molecular marker in forty varieties

\begin{tabular}{|c|c|c|c|c|c|c|c|}
\hline \multirow[b]{2}{*}{ S. No. } & \multirow[b]{2}{*}{ Name of variety } & \multicolumn{6}{|c|}{ Known gene marker } \\
\hline & & $\begin{array}{c}\operatorname{Lr68} \\
\text { CsGs-STS }\end{array}$ & $\begin{array}{c}\mathrm{Lr} 24 / \mathrm{Sr} 24 \\
\mathrm{Sr} 24 \# 50\end{array}$ & $\begin{array}{c}\operatorname{Lr} 34 / Y r 18 / \\
\text { Sr57 } \\
\text { csLV34 }\end{array}$ & Sr 2 gwm 533 & Sr 28 wpt 7004 & $\begin{array}{c}\mathrm{Yr} 9 / \mathrm{Lr} 26 / \mathrm{Sr} 31 \\
\text { iag95 }\end{array}$ \\
\hline 1. & DBW71 & - & - & + & - & - & + \\
\hline 2. & DBW88 & - & - & - & - & - & - \\
\hline 3. & DBW90 & + & - & - & - & - & - \\
\hline 4. & DBW93 & - & - & - & - & - & + \\
\hline 5. & DBW107 & - & - & + & - & - & + \\
\hline 6. & DBW110 & + & - & - & - & - & - \\
\hline 7. & DPW621-50 & - & - & - & - & - & - \\
\hline 8. & HD3043 & + & - & - & - & - & + \\
\hline 9. & HD3059 & - & - & - & - & - & - \\
\hline 10. & HD3086 & + & - & - & - & - & - \\
\hline 11. & HD3090 & - & + & - & - & - & + \\
\hline 12. & HD3118 & + & - & - & - & - & - \\
\hline 13. & HI1563 & - & + & + & - & - & - \\
\hline 14. & HI8713 (d) & - & - & - & + & + & - \\
\hline 15. & HI8737 (d) & - & - & - & + & + & - \\
\hline 16. & HPW349 & - & - & + & - & - & - \\
\hline 17. & HS507 & - & - & + & - & - & + \\
\hline 18. & HS542 & + & - & + & - & - & - \\
\hline 19. & HW1098 (d) & - & - & - & + & + & - \\
\hline 20. & HW5216 & - & + & - & - & - & + \\
\hline
\end{tabular}


Table 4 (cont.)

\begin{tabular}{|c|c|c|c|c|c|c|c|}
\hline \multirow[b]{2}{*}{ S. No. } & \multirow[b]{2}{*}{ Name of variety } & \multicolumn{6}{|c|}{ Known gene marker } \\
\hline & & $\begin{array}{c}\operatorname{Lr68} \\
\text { CsGs-STS }\end{array}$ & $\begin{array}{c}L r 24 / S r 24 \\
S r 24 \# 50\end{array}$ & $\begin{array}{c}\text { Lr34/Yr18/ } \\
\text { Sr57 } \\
\text { csLV34 }\end{array}$ & Sr 2 gwm 533 & Sr28 wpt7004 & $\begin{array}{c}\text { Yr9/Lr26/Sr31 } \\
\text { iag95 }\end{array}$ \\
\hline 21. & K1006 & + & - & - & - & - & - \\
\hline 22. & MACS6478 & - & - & - & - & - & - \\
\hline 23. & MP3288 & - & + & - & - & - & - \\
\hline 24. & MP3336 & - & - & - & - & - & - \\
\hline 25 . & NIAW1415 & - & + & - & - & - & + \\
\hline 26. & NW5054 & - & - & - & - & - & - \\
\hline 27. & PBW644 & + & - & + & - & - & - \\
\hline 28. & PBW660 & - & - & - & - & - & + \\
\hline 29. & PDW315 (d) & - & - & - & + & + & - \\
\hline 30. & RAJ4229 & - & + & + & - & - & - \\
\hline 31. & RAJ4238 & - & + & - & - & - & - \\
\hline 32. & TL2969 (T) & - & - & - & - & - & + \\
\hline 33. & UAS347 & - & - & - & - & - & - \\
\hline 34. & UAS428 (d) & - & - & - & + & + & - \\
\hline 35. & UAS446 (d) & - & - & - & - & + & - \\
\hline 36. & WH1080 & - & - & - & - & - & - \\
\hline 37. & WH1105 & - & - & - & - & - & - \\
\hline 38. & WH1142 & - & - & - & - & - & + \\
\hline 39. & WH1124 & - & - & - & - & - & - \\
\hline 40. & WHD948 (d) & - & - & - & - & + & - \\
\hline
\end{tabular}

\section{Discussion}

Lr34 has been widely recognized as a major component of durable rust resistance as it can act synergistically with other leaf rust resistance genes. The associated character leaf tip necrosis $(L t n 1)$ is not unique to this gene since two other disease resistance gene complexes $Y r$ 29/Lr46/Pm39Ltn2 and $Y r 46 / L r 67 / S r 55 / P m 46 / L t n 3$ are also linked with the leaf tip necrosis (McIntosh et al. 2017). Lagudah et al. (2006) developed the STS marker, csLV34 that maps $0.4 \mathrm{cM}$ from $L r 34$, and was validated in many lines and cultivars from different wheat breeding programmes. Marker analysis helped to resolve the identification of $L r 24 / S r 24$ where IT data were insufficient to show the presence of this gene. The marker $S r 24 \# 50$ was able to confirm $L r 24 / S r 24$ gene in all seven cultivars which were completely resistant to leaf rust pathotypes. In the present study APR gene $\operatorname{Lr} 68$ was identified in nine Indian wheat cultivars. Lr68 first reported by Herrera-Foessel et al. 
(2012) in spring wheat Parula, that traced back to Brazilian cultivar Frontana that conferred higher level of resistance than $\operatorname{Lr} 34$ (Silva et al. 2015). Sr2 was postulated in 26 cultivars on the basis of seedling morphological marker (micro-flecking). All the five cultivars identified with $S r 2$ through gwm533 also showed micro-flecking character at seedling stage. However, gwm533 failed to identify $\operatorname{Sr} 2$ in all the cultivars with seedling chlorosis. Seedling chlorosis or micro-flecking is very reliable marker for identification of $\mathrm{Sr} 2$ which was previously monitored by the appearance of pseudo-black chaff on glumes or upper stem or the expression of resistance (Brown 1997).

There has been evolution of very virulent pathotypes of wheat rusts over the years in India. Consequently, most of the rust resistance genes in present day wheat material do not condition resistance when present singly. However, wheat lines with $\mathrm{Lr} 24 / \mathrm{Sr} 24$ are resistant to present day field population of leaf and stem rusts. While lines with $\mathrm{Sr} 31$ are resistant to stem rust of wheat, $\operatorname{Lr26} / \mathrm{Yr} 9$ do not condition effective resistance to leaf and stripe rust. In addition, $\operatorname{Lr} 13$ to leaf rust, $S r 2$ to stem rust and $\mathrm{YrA}$ to stripe rust also confer substantial rust resistance when present in different combinations with the characterized resistance genes (Bhardwaj 2011).

This study confirmed the presence and utilization of $\operatorname{Sr} 28$ gene in seven durum wheat lines. Infection type data with different pathotypes was not able to detect the presence $\mathrm{Sr} 28$ in these lines. Sr 28 is known to confer resistance to Ug99 pathotypes of stem rust (Bhardwaj et al. 2003; Singh et al. 2011). Marker wPt-7004-PCR (Rouse et al. 2012) derived from a DaRT locus linked to $\mathrm{Sr} 28$ was used to map this gene. Markers wmc332 and $w P t-7004-P C R$ were validated in a panel of 24 hard red spring wheat varieties and seven other wheat lines. Lines with and without $\mathrm{Sr} 28$ could be differentiated by the preferential and repeatable amplification of each product. Preferential amplification of the 194-bp amplicon was associated with the presence of Sr28. In contrast, the susceptible genetic stocks and all the US hard red spring wheat cultivars had either equal amplification or preferential amplification of the 166-bp amplicon. Equal amplification of both 166-bp and 194-bp was observed in four Indian cultivars and these do not carry Sr28. This gene provides resistance against stem rust in some areas (about 5 million hectares) of Peninsular and central India. However, in some stem rust prone areas, alone it does not provide resistance to all the pathotypes. To obtain highly effective and durable resistance, $\mathrm{Sr} 28$ is being used in combination with additional stem rust resistance genes like $\mathrm{Sr} 24$, Sr31 and Sr32. The STS marker iag95 confirmed the presence of the $\mathrm{Yr}$ 9/Lr26/Sr31/Pm8 gene complex in the genotypes which showed complete resistance to stripe rust pathotypes.

The cultivars under study have not been breed through MAS for rust resistance and other traits. The information of resistance genes present in these genotypes will be of great help to wheat breeders to select parents for resistance breeding. The present finding will also be helpful in strategy for management of wheat rusts through gene deployment. The rust management strategy has now shifted towards the use of combination of genes or genes with minor effects to develop varieties with durable resistance and ultimately deployment of varieties with diverse rust resistance (Bhardwaj et al. 2010b). Park (2007) emphasized the importance of creating complex rust resistance by using durable genetic 
backgrounds, e.g. Sr2, $\mathrm{Lr} 34 / \mathrm{Yr} 18$ and Lr46/Yr29, with which other effective genes are added. Breeders that rely solely on phenotypic selection rarely know about presence or absence of resistance gene in the selected progenies. During selection cycles many minor and adult plant resistance genes are lost. The robust markers can greatly help in the selection and pyramiding of resistance gene in wheat breeding programme.

\section{Acknowledgement}

We are grateful to the Director, ICAR-IIWBR, Karnal, Haryana, 132 001-India for providing the necessary facilities and funds to carry out the research.

\section{References}

Bansal, U.K., Hayden, M.J., Gill, M.B., Bariana, H.S. 2010. Molecular mapping of a seedling stripe rust resistance gene in wheat cultivar Rubric. Euphytica 171:121-127.

Bansal, U., Bariana, H., Wong, D., Randhawa, M., Wicker, T., Hayden, M., Keller, B. 2014. Molecular mapping of an adult plant stem rust resistance gene Sr56 in winter wheat cultivar Arina. Theor. Appl. Genet. 127:1441-1448.

Bariana, H.S., McIntosh, R.A. 1995. Genetics of adult plant stripe rust resistance in four Australian wheats and the French cultivar 'Hybride de Bersee'. Plant Breed. 114:485-491.

Bariana, H.S., McIntosh, R.A. 1993. Cytogenetic studies in wheat XV. Location of rust resistance genes in VPM1 and their genetic linkage with other disease resistance genes in chromosome 2A. Genome 36:476482.

Bariana, H.S., Brown, G.N., Ahmed, N.U., Khatkar S., Conner, R.L., Wellings, C.R., Haley, S., Sharp, P.J., Laroche, A. 2002. Characterization of Triticum vavilovii-derived stripe rust resistance using genetic, cytogenetic and molecular analyses and its marker-assisted selection. Theor. Appl. Genet. 104:315-320.

Bariana, H.S., Brown, G.N., Bansal, U.K., Miah, H., Standen, G.E., Lu, M. 2007. Breeding triple rust resistant wheat cultivars for Australia using conventional and marker-assisted selection technologies. Austr. J. Agric. Res. 58:576-587.

Bhardwaj, S.C. 2011. Resistance genes and adult plant resistance of released wheat varieties of India. Regional Station, Directorate of Wheat Research. Flowerdale, Shimla-171002 HP. India. Res. Bull. No. 5. 31 p.

Bhardwaj, S.C., Nayar, S.K., Prashar, M., Jain, S.K., Singh, S.B. 2003. Diversity of resistance for Puccinia graminis tritici in wheat (Triticum aestivum) and triticale material. Indian J. Agric. Sci. 73:676-679.

Bhardwaj, S.C. 2013. Puccinia-Triticum interaction: an update. Indian Phytopathol. 66:14-19.

Bhardwaj, S.C., Prashar, M., Jain, S. K., Kumar, S., Datta, D. 2010a. Adult plant resistance in some Indian wheat genotypes and postulation of leaf rust resistance genes. Indian Phytopathol. 63:174-180.

Bhardwaj, S.C., Prashar, M., Jain, S.K., Kumar, S., Sharma, Y.P., Sivasamy, M. 2010b. Virulence of Puccinia triticina on $\operatorname{Lr} 28$ in wheat and its evolutionary relation to prevalent pathotypes in India. Cereal Res. Commun. 38:83-89.

Bhardwaj, S.C., Gangwar, O.P., Singh, S.B., Saharan, M.S., Sharma, S. 2012. Rust situation and pathotypes of Puccinia species in Leh Ladakh in relation to recurrence of wheat rusts in India. Indian Phytopathol. 65:230-232.

Biffen, R.H. 1931. The cereal rusts and their control. Transactions of the British Mycological Society 16:19-37.

Browder, L.E. 1973. Probable genotype of some Triticum aestivum 'Agent' derivatives for reaction to Puccinia recondita f. sp. tritici. Crop Sci. 13:203-206.

Brown, G.N. 1997. The inheritance and expression of leaf chlorosis associated with gene $\operatorname{Sr} 2$ for adult plant resistance to wheat stem rust. Euphytica 95:67-71.

Don, R.H., Cox, P.T., Wainwright, B.J., Baker, K., Mattick, J.S. 1991. Touchdown PCR to circumvent spurious priming during gene amplification. Nucleic Acids Res. 19:4008. 
Herrera-Foessel, S.A., Singh, R.P., Huerta-Espino, J., Rosewarne, G.M., Periyannan, S.K., Viccar, L., CalvoSalazar, V., Lan, C., Lagudah, E.S. 2012. Lr68: a new gene conferring slow rusting resistance to leaf rust in wheat. Theor. Appl. Genet. 124:1475-1486.

Johnson, R. 1988. Durable resistance to yellow (stripe) rust in wheat and its implications in plant breeding. In: Simmonds, N.W., Rajaram, S. (eds), Breeding Strategies for Resistance to the Rusts of Wheat. CIMMYT. Mexico. pp. 63-75.

Kolmer, J.A. 1996. Genetics of resistance to wheat leaf rust. Annu. Rev. of Pathol. 34:435-455.

Lagudah, E.S., Mcfadden, H., Singh, R.P., Heurta-Espino, J., Bariana, H.S., Spielmyer, W. 2006. Molecular genetic characterization of the $L r 34 / Y r 18$ slow rusting resistance gene region in wheat. Theor. Appl. Genet. 114:21-30.

Loegering, W.Q., McIntosh, R.A., Burton, C.H. 1971. Computer analysis of disease data to drive hypothetical genotypes for reaction of host varieties to pathogens. Can. J. of Genet. and Cytol. 13:149-154.

Luig, N.H. 1983. A survey of virulence genes in wheat stem rust Puccinia graminis f. sp. tritici. Advances in Plant Breeding (Suppl. 11 to Plant Breeding). Verlag Paul Parey. Berlin, Germany.

Mago, R., Bariana, H.S., Dundas, L.S., Speilmeyer, W., Lawrence, G.J., Pryor, A.J., Ellis, J.G. 2005. Development of PCR markers for the selection of wheat stem rust resistance genes $\mathrm{Sr} 24$ and $\mathrm{Sr} 26$ in diverse wheat germplasm. Theor. Appl. Genet. 111:496-504.

McCartney, C.A., Somers, D.J., McCallum, B.D., Thomas, J., Humpherys, D.G., Menzies, J.G. Brown, P.D. 2005. Microsatellite tagging of leaf rust resistance gene Lr16 on wheat chromosome 2BS. Mol. Breed. 15:329-337.

McIntosh, R.A., Dubcovsky, J., Rogers, W.J., Morris, C., Xia, X.C. 2017. Catalogue of Gene Symbols for Wheat: 2017 Supplement. In: KOMUGI-Integrated Wheat Science Database. http://shigen.nig.ac.jp/wheat/ komugi/genes/macgene/supplement2017.pdf

Nagarajan, S., Nayar, S.K., Bahadur, P., Kumar, J. 1986. Wheat Pathology and Wheat Improvement. I.A.R.I., Regional Station, Flowerdale, Shimla 171002, India. 12 p.

Nayar, S.K., Prashar, M., Bhardwaj, S.C. 1997. Manual of current techniques in wheat rusts. Regional Station, Directorate of Wheat Research. Flowerdale, Shimla-171002, India. Res. Bull. No.2: 32 p.

Park, R.F. 2007. Stem rust of wheat in Australia. Austr. J. Agric. Res. 58:558-566.

Prins, R., Groenewald, J.Z., Marais, G.F., Snape, J.W., Koebner, R.M.D. 2001. AFLP and STS tagging of Lr19, a gene conferring resistance to leaf rust in wheat. Theor. Appl. Genet. 103:618-624.

Rouse, M.N., Wanyera, R., Njau, P., Jin, Y. 2011. Sources of resistance to stem rust race Ug99 in spring wheat germplasm. Plant Dis. 95:762-766.

Rouse, M.N., Nava, I.C., Chao, S., Anderson, J.A., Jin, Y. 2012. Identification of markers linked to the race Ug99 effective stem rust resistance gene Sr28 in wheat (Triticum aestivum L.). Theor. Appl. Genet. 125:877-885.

Saini, R.G., Kaur, M., Singh, B., Sharma, S., Nanda, G.S., Nayar, S.K., Gupta, A.K., Nagrajan, S. 2002. Lr48 and Lr49, novel hypersensitive adult plant leaf rust resistance genes in wheat (Triticum aestivum L.). Euphytica 124:365-370.

Silva, P., Calvo-Salazar, V., Condón, F., Quincke, M., Pritsch, C., Gutiérrez, L., Herrera-Foessel, S., von Zitzewitz, J., German, S. 2015. Effects and interactions of genes Lr34, Lr68 and Sr2 on wheat leaf rust adult plant resistance in Uruguay. Euphytica 204:599-608.

Singh, R.P. 1992. Genetic association of leaf rust resistance gene Lr34 with adult plant resistance to stripe rust in bread wheat. Phytopathol. 32:835-838.

Singh, R.P., Rajaram, S. 1994. Genetics of adult plant resistance to stripe rust in ten bread wheats. Euphytica 72:1-7.

Singh, R.P., Huerta-Espino, J., Rajaram, S. 2000. Achieving near immunity to leaf and stripe rusts in wheat by combining slow rusting resistance genes. Acta Phytopathol. et Entomologica Hungarica 35:133-139.

Singh, R.P., Hodson, D.P., Huerta-Espino, J., Jin, Y., Bhavani, S., Njau, P., Herrera-Foessel, S., Singh, P.K., Singh, S., Singh, V.G. 2011. The emergence of Ug99 races of the stem rust fungus is a threat to world wheat production. Annu. Rev. Phytopathol. 49:465-481.

Spielmeyer, W., Sharp, P.J., Lagudah, E.S. 2003. Identification and validation of markers linked to broad spectrum stem rust resistance gene $S r 2$ in wheat (Triticum aestivum L.). Crop Sci. 43:333-336. 
Stakman, E.C., Stewart, D.M., Loegering, W.Y. 1962. Identification of physiologic races of Puccinia graminis var. tritici. United States Department of Agriculture Technical Bulletin ARS E-617.

Stubbs, R.W. 1985. Stripe rust. In: Roelfs, A.P., Bushnell, W.R. (eds), The Cereal Rusts. Vol. 2. Diseases, Distribution, Epidemiology and Control. Academic Press. Orlando, FL, USA, pp. 61-101.

\section{Electronic Supplementary Material (ESM)}

Electronic Supplementary Material (ESM) associated with this article can be found at the website of CRC at http://www.akademiai.com/content/120427/

Electronic Supplementary Table S1. Constitution of differential sets 0, A and B for designation of pathotypes of wheat rust pathogen in India

Electronic Supplementary Table S2. Infection types of the rust gene/gene-combination postulated in the Indian wheat cultivars 